\title{
Growth Response of Soybean Varieties to Trichoderma Application on Acid Soils
}

\author{
Sutarman $^{*}$ and $A$. Miftahurrohmat \\ Department of Agrotechnology, Faculty of Science and Technology, Universitas Muhammadiyah \\ Sidoarjo, Indonesia
}

\begin{abstract}
This study aims to determine the growth response of the vegetative stadia of three soybean varieties which are widely used in East Java on acid soils that have been given biological fertilizers from various Trichoderma isolates. The experiment was arranged factorially using a completely randomized design. The first factor was the variety consisting of Detam 3, Detam 4, Gema, Dering 1, and Burangrang. The second factor was Trichoderma isolates formulated as bio fertilizers, consisting of Tc-Jjr02, Tc-Pjn-01, and Tc-Jro-01. Overall this experiment has 60 experimental units. Data were analyzed by variance analysis (ANOVA) followed by an honest significant difference test at the level of 5\%. The results showed that there was no interaction between soybean varieties and Trichoderma isolates formulated in bio fertilizer. Soybean varieties significantly affected plant height, wet weight, and dry weight of roots and stover at 21 days after planting. The Burangrang variety shows the best growing ability in acid soils. There was no interaction between soybean varieties and Trichoderma bio fertilizers. Trichoderma isolate Tc-Jjr-02 increased the wet weight and dry weight of the roots and roots by 48.2 and $54.5 \%$, respectively, and 38.9 and $48.2 \%$ compared to without Trichoderma. Trichoderma application maintains soil acidity between $\mathrm{pH}$ 4.50-4.67.
\end{abstract}

\section{Introduction}

Soybean as an important food industry ingredient in the world has a major impact on the adequacy of food and the health of the human body as well as the adequacy of animal feed [1]. The world demand for soybeans, which has increased rapidly in the last two decades, has encouraged crop expansion to marginal lands [2]. The decline in planting area and productivity of soybean in the past two decades has made Indonesia a constant importer of soybean because it is only able to produce no more than $40 \%$ of the national soybean needs [3]. The obstacles faced in order to utilize dry land as a measure for soybean expansion include low soil acidity and soil fertility [4]. Soil $\mathrm{pH} \leq 5.5$ or known as acid soil will produce high $\mathrm{Al}$ availability and is toxic to plants [5] and causes deficiency of macronutrients such as $\mathrm{P}, \mathrm{Ca}$, and $\mathrm{Mg}$ [6]. Application of lime and phosphate fertilization is another alternative to overcome soil acidity [7], but it requires an additional production cost which is not small and is often faced with the availability of materials. Research objectives

\footnotetext{
${ }^{*}$ Corresponding author: sutarmans234@gmail.com
} 
are to find and utilize soybean germ plasma sources that are tolerant of soil acidity needs to be developed. Variety variability testing needs to be done considering that different varieties will show different levels of tolerance to soil acidity [8-9]. On the other hand, it is necessary to carry out more careful study and testing when various potential varieties of marginal land are juxtaposed with biological agents of the potential rhizosphere components to assist plant growth.

One of the important biological agents in the rhizosphere is the Trichoderma fungus. These fungi are cosmopolitan, easy to find from soil and organic matter [10]. Besides acting as mycoparasites against pathogenic fungi, it also produces metabolites that act as growth hormones for plants [11]. The results of the decomposition of organic matter by the Trichoderma fungus [12] are expected to support the growth of soybean plants. On the other hand, Trichoderma is able to live well on acid soils and even some of them are able to show optimal activity at a $\mathrm{pH}$ of less than 5.5 [13].

Testing the ability of various soybean varieties to overcome acid soil stress needs to be carried out. The growth of young plants, the speed at which they grow, and the success of seed germination are highly dependent on environmental conditions [14]. Meanwhile, the Trichoderma fungus which has the potential as a biological fertilizer agent also needs to be tested for its ability to survive and play a role in helping plants in acidic soil conditions. From the combination of testing between varieties and the application of Trichoderma fungi as biological fertilizers, it is expected to know how far the potential interactions can increase the performance of soybean plants in acid soils. The ability of plants and their life partners in the rhizosphere in facing acidic soil stress can be seen in the growth performance of soybean plants in the early vegetative phase. A good ability to live in this phase will guarantee optimal production success.

This study aims to determine the three-stage growth response of various soybean varieties that are widely used in East Java grown on acid soils that have been given biological fertilizers from various Trichoderma isolates.

\section{Methods}

\subsection{Preparation and planting}

Three Trichoderma isolates, namely Tc-Jjr-02, Tc-Pjn-01, and Tc-Jro-01 (collection of the Microbiology Laboratory of Muhammadiyah University, Sidoarjo) were cultured in PDA$\mathrm{m}$ media [15]. 10 days the culture is harvested and formulated as biofertilizer with compost carrier that has been sterilized in autoclave. By adjusting the propagule suspension dilution, the conidiophores population of each Trichoderma in the compost was made the same, namely $10^{8}$ CFU.g ${ }^{-1}$. Compost that already contains Trichoderma isolates is ready to be applied as biological fertilizers. Meanwhile, alpha soil was prepared from former paddy fields planted with local varieties of soybean in Purwojati village, Ngoro sub-district, Mojokerto district, East Java with an average $\mathrm{pH}$ of 4.8; thus this land can be said to be acid soil.

In this study, indigenous nodule bacteria were used which were isolated from local soybean root nodules and reproduced in PDA media. The acid soil is to be used as a planting medium, mashed and sieved through a 100 mesh sieve, and sterilized in an autoclave. The soil is then put into the polybag with a capacity of $5 \mathrm{~kg}$. Furthermore, the soil is composted at a dose of $200 \mathrm{~g}$ per polybag. For the biological fertilizer treatment, the compost was given with the same dosage as the treatment without Trichoderma but contained $2 \times 10^{10}$ CFU.g ${ }^{-1}$ of Trichoderma conidiophores. Thus, one polybag contained an average of $4 \times 10^{6}$ CFU.g ${ }^{-1}$ of planting medium. The soybean seeds tested in this study were 
five varieties of soybean seeds obtained from Balitkabi - Department of Agriculture, Malang, East Java. The five varieties are Detam 3 and Detam 4, which are black soybeans that are commonly used to make soy sauce, while the other three varieties (Gema, Dering 1 , and Burangrang) are types of soybean commonly used as the main ingredient for making tofu and tempeh. Soybean seeds from the five varieties were germinated on sterile paper towels soaked in aqua dest to maintain moisture and were inoculated with propagules/nodule bacterial cells taken from the culture with a population average of $10^{9}$ CFU.ml ${ }^{-1}$ suspensions. Germination is uniformly regulated so that when transplanting into polybags they have the same germination size. The day before planting, the soil $\mathrm{pH}$ was measured and the soil chemical analysis was carried out, especially the content of N, P. K, $\mathrm{Na}, \mathrm{Ca}, \mathrm{Mg}$, and soil cation exchange capacity. Fertilization is done once at the age of 14 days after planting, which is equivalent to $18.75 \mathrm{~kg} \cdot \mathrm{ha}^{-1} \mathrm{~N}, 50.00 \mathrm{~kg}^{-h a^{-1}} \mathrm{P} 2 \mathrm{O}$, and 18.75 $\mathrm{kg} . \mathrm{ha}^{-1} \mathrm{~K} 2 \mathrm{O}$ [16]. Since mixing until the end of the savings, which is 21 days after planting and is considered the end of stage 3 vegetative soybean, no fertilizer is given except for compost which is a component of the growing media in this experiment.

\subsection{Experimental design}

This factorial experiment was arranged in a completely randomized design (CRD). The first factor is the types of varieties consisting of Detam 3 (V1), Detam 4 (V2), Echo (V3), Dering 1 (V4), and Burangrang (V5). The second factor was the type of Trichoderma isolate, the biological fertilizer agent consisting of: without Trichoderma (T0), isolate TcClkt-01 (T1), isolate Tc-Jro-01 (T2). And isolate Tc-Jjr-02 (T3). With 3 repetitions, a total of 60 experimental units were obtained. The variables observed in this experiment were: plant height $(\mathrm{cm})$, stem diameter $(\mathrm{cm})$, number of leaves, wet and dry weight of roots $(\mathrm{g})$, wet and dry weight of roots (g), wet and dry weight of stover ( $\mathrm{gr}$ ), and the $\mathrm{pH}$ of the planting medium.

\subsection{Statistical analysis}

All data were analyzed using analysis of variance (level 5\%) to determine whether there was an effect of treatment on the response of plants in terms of vegetative growth until the end of the vegetative stage 3 . With respect to the results of the analysis of the very significant variety of observational variables $(p<0.01)$, the Honest Significant Difference (HSD) test was performed at the $5 \%$ level.

\section{Results and discussion}

\subsection{The plant growth}

The results of the analysis of variance showed that soybean varieties had a significant effect $(p<0.05)$ on plant height up to 21 days after planting (DAP), but had no significant effect on stem diameter and a number of leaves per plant $(\mathrm{p}>0.05)$. Trichoderma and its interaction with soybean varieties had no significant effect $(p>0.05)$ on height, stem diameter, and number of leaves per plant from 7 to 21 DAP. The average plant heights of 7-21 DAP in all tested soybean varieties is shown in Figure 1. 


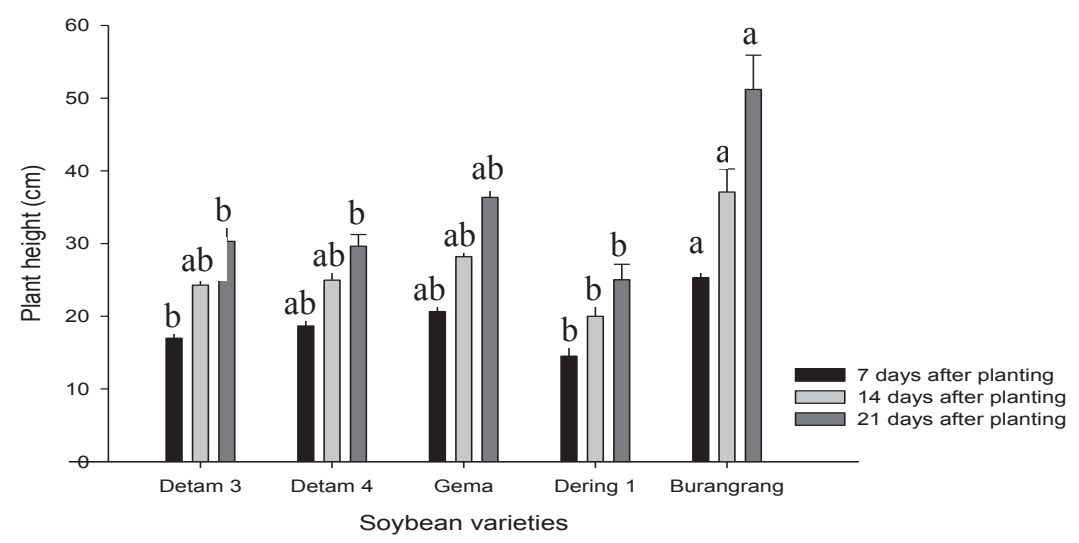

Fig. 1. The mean of plant height for various varieties of soybeans at 7-21 DAP (cm). Different letters on top of the same bars showed a significant difference between varieties according to the HSD test $(\mathrm{p}<0.05)$.

\subsection{Biomass production}

\subsubsection{Wet and dry weight of roots}

The results of the analysis of variance showed that the Trichoderma variety and isolate of biological fertilizer had a significant effect $(\mathrm{P}<0.05)$ on root wet weight; however, in terms of dry weight, only varieties had a significant effect. The interaction between varieties and Trichoderma isolates did not significantly affect both wet weight and root dry weight. The mean wet and dry weight for all varieties is shown in Figure 2, meanwhile, the mean wet and dry weight of the roots in the Trichoderma isolate treatment can be seen in Figure 3.

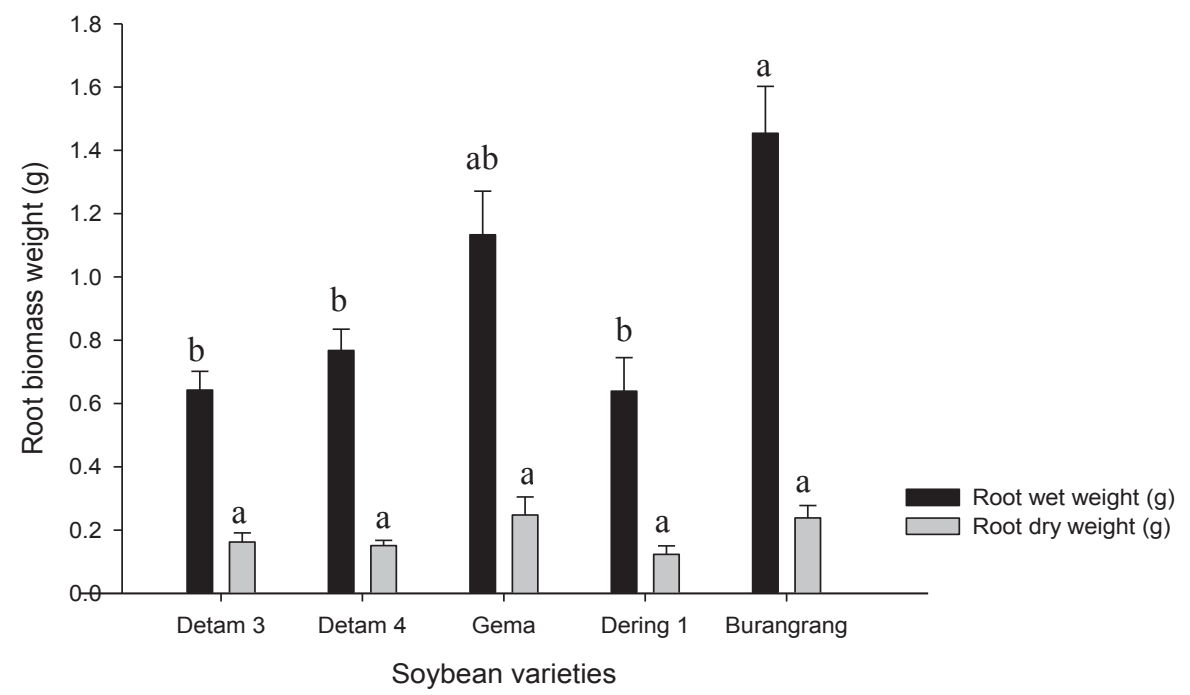


Fig. 2. The mean of wet weight and dry weight of roots in varieties of soybeans at 21 DAP various Trichoderma isolates (gr). Different letters on top of the same bars showed a significant difference between varieties according to the HSD test $(\mathrm{p}<0.05)$

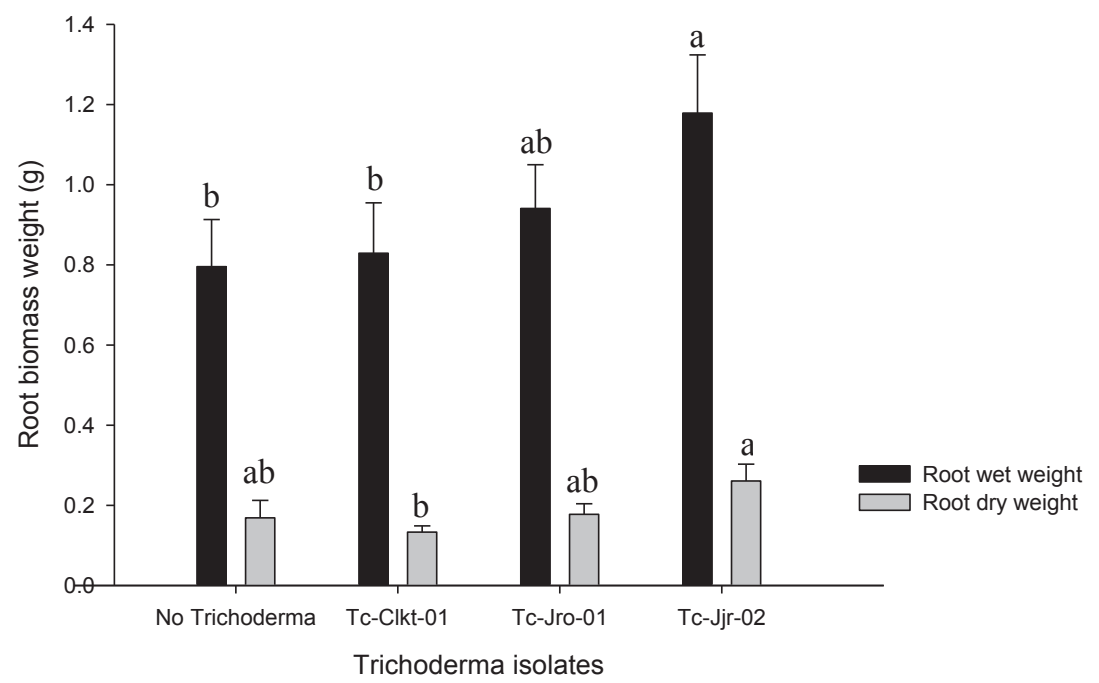

Fig. 3. The mean of wet weight and dry weight of roots in various Trichoderma isolates at 21 DAP (gr). Different letters on top of the same bars showed a significant difference between the applications of Trichoderma isolates according to the HSD test $(\mathrm{p}<0.05)$

\subsubsection{Wet and dry weight of stover}

The results of the analysis of variance showed that the variety only had a significant effect $(p<0.05)$ on the wet weight of stover. Trichoderma isolates and their interactions with varieties had no significant effect on the wet weight and dry weight of stover at the end of the vegetative stage 3 . The mean wet and dry weights in all treatment varieties are presented in Figure 4, while all Trichoderma isolates are presented in Figure 5.

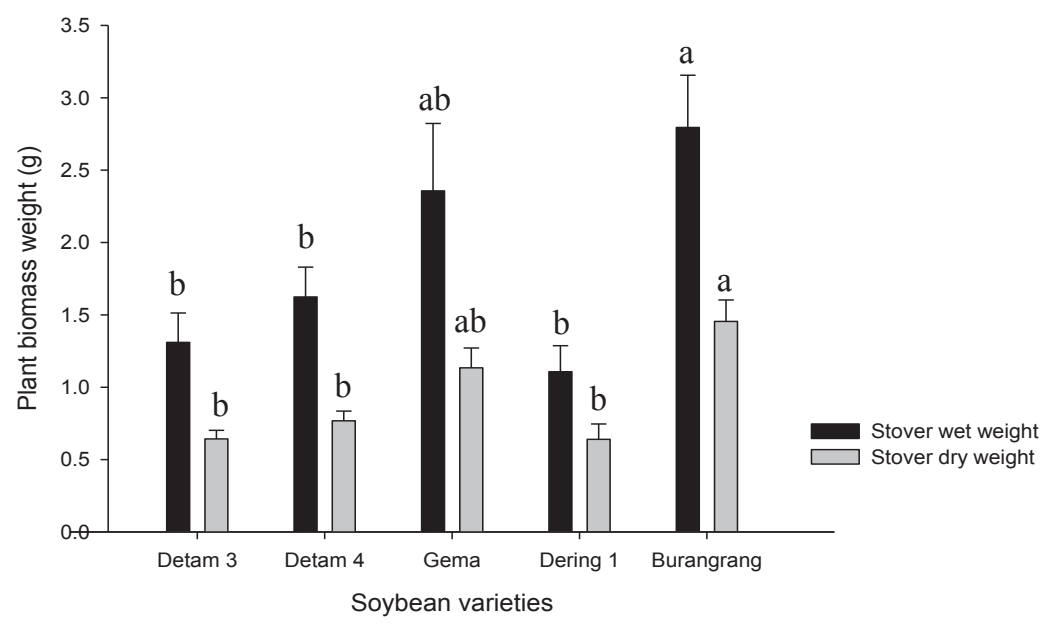


Fig. 4. The mean of wet weight and dry weight of stover in varieties of soybeans at 21 DAP various Trichoderma isolates (gr). Different letters on top of the same bars showed a significant difference between varieties according to the HSD test $(\mathrm{p}<0.05)$

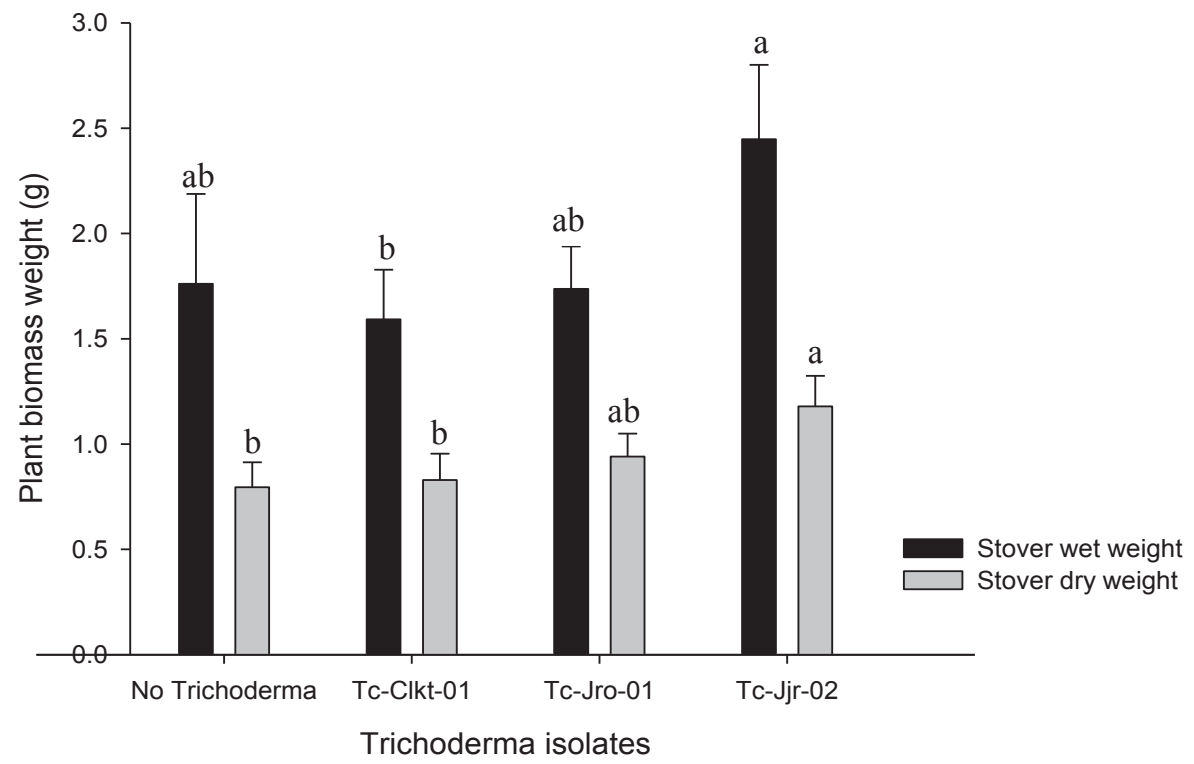

Fig. 5. The mean of wet weight and dry weight of stover in various Trichoderma isolates at 21 DAP (gr). Different letters on top of the same bars showed a significant difference between the applications of Trichoderma isolates according to the HSD test $(\mathrm{p}<0.05)$

The Detam 3, Detam 4, Gema, and Dering 1 varieties showed suboptimal vegetative growth. The total growth biomass represented by root wet weight and stover wet weight (Figures 2 and 4) appeared to be lower than Burangrang. This shows that the four varieties are less tolerant of acidic stress. Low $\mathrm{pH}$ soils will increase Al solubility [17], low P availability [18], N deficiency, and other nutrients [19] and inhibit plant root symbiosis with Rhizobium [20]; thus $\mathrm{Al}$ is the cause of the decline in all agronomic parameters [21].

Until the end of the third stage of vegetative growth, the Burangrang variety showed the highest values in almost all parameters, namely plant height (Figure 1), wet weight and dry weight of roots (Figure 2), and wet weight and dry weight of stover (Figure 4). This indicates that Burangrang is more tolerant than other varieties in dealing with soil acidity stress during the early vegetative growth period.

The differences in the response of soybean plants in different varieties reflect differences in genetic potential in responding to environmental influences including acid soil stress. However, these five varieties are not acid-tolerant varieties [22]. Therefore, the appearance of vegetative growth in stage three is likely influenced by Trichoderma activity in the rhizosphere.

Of the three isolates tested and compared with the treatment without Trichoderma, it was seen that the isolate Tc-Jjr-02 gave a higher plant response in terms of wet weight and dry weight of roots (Figure 3), as well as wet weight and dry weight of stover (Figure 5). It appears that Tc-Jjr-02 is able to play its role in producing plant growth hormone [23-24], various enzymes that degrade organic matter [25-26] that produce nutrients for plants, producing various important metabolites [27] that can support growth and plant health [28]. 
Auxins affect stem growth [29] and their synergy with cytokines is closely related to root growth.

\subsection{Planting media $\mathrm{pH}$ and Trichoderma population}

Based on the analysis of variance, it was found that soybean varieties and Trichoderma isolates and the interaction between them did not significantly affect the $\mathrm{pH}$ of the growing media $(\mathrm{p}>0.05)$. The mean soil $\mathrm{pH}$ of growing media on soybean varieties and Trichoderma isolates is presented in Table 1.

Table 1. The mean soil $\mathrm{pH}$ of growing media on several soybean varieties and isolates of Trichoderma 21 DAP

\begin{tabular}{|l|l|l|l|}
\hline \multicolumn{1}{|c|}{ Variety } & soil $\mathbf{p H}^{*}$ & Trichoderma isolates of biofertilizer & soil $\mathbf{p H}{ }^{*}$ \\
\hline Detam 3 & $4.63 \pm 0.11$ & Without Trichoderma & $4.67 \pm 0.12$ \\
\hline Detam 4 & $4.58 \pm 0.14$ & Trichoderma Tc-Clkt-01 & $4.60 \pm 0.10$ \\
\hline Gema & $4.54 \pm 0.13$ & Trichoderma Tc-Jro-01 & $4.57 \pm 0.12$ \\
\hline Dering 1 & $4.54 \pm 0.13$ & Trichoderma Tc-Jjr-02 & $4.50 \pm 0.12$ \\
\hline Burangrang & $4.54 \pm 0.13$ & & \\
\hline
\end{tabular}

*) The $\mathrm{pH}$ of the soil at the beginning of planting is $4.80 \pm 0.12$

Both the varieties and Trichoderma isolates and their interactions did not significantly affect the Trichoderma population at the end of the observation $(p>0.05)$. The mean population of Trichoderma in various soybean varieties and some Trichoderma isolates is shown in Table 2.

The highest living population of Trichoderma conidiospores was found in the soil of the Detam 3 variety soybean planting medium, namely $2.31 \times 10^{7} \mathrm{CFU} \cdot \mathrm{g}^{-1}$, followed by Gema, Dering 1, and Detam 4 at 21 DAP. On the other hand, at the end of the observation (21 DAP), it appears that the conidiospores of the Tc-Jjr-02 isolate showed the highest population.

Table 2. The mean populations of Trichoderma conidiophores on soybean varieties and Trichoderma isolates at $21 \mathrm{DAP}$

\begin{tabular}{|l|c|l|c|}
\hline Variety & $\begin{array}{c}\text { Population of Trichoderma } \\
\text { conidiospores (CFU.gr } \\
\text { soil) }\end{array}$ & $\begin{array}{l}\text { Trihcoderma } \text { isolates } \\
\text { of biofertilizer }\end{array}$ & $\begin{array}{c}\text { Population of Trichoderma } \\
\text { conidiospores (CFU.gr } \\
\text { soil) }\end{array}$ \\
\hline of \\
\hline Detam 3 & $2.31 \times 10^{7}$ & Without Trichoderma & 0 \\
\hline Gema & $1.17 \times 10^{7}$ & $\begin{array}{l}\text { Trichoderma } \text { Tc-Clkt- } \\
01\end{array}$ & $2.06 \times 10^{7}$ \\
\hline Dering 1 & $1.61 \times 10^{7}$ & $\begin{array}{l}\text { Trichoderma } \text { Tc-Jro- } \\
01\end{array}$ & $0.96 \times 10^{7}$ \\
\hline Burangrang & $1.45 \times 10^{7}$ & $\begin{array}{l}\text { Trichoderma } \text { Tc-Jjr- } \\
02\end{array}$ & $2.84 \times 10^{7}$ \\
\hline
\end{tabular}

All tested Trichoderma isolates were unable to increase the soil $\mathrm{pH}$ of the growing media, although it has been reported that this fungus is able to cope with copper stress [30] in acid soils. In this experiment, it appears that this fungus is unable to cope with acid soil stress which increases the availability of metals, especially $\mathrm{Al}$ [17]. Soil with a $\mathrm{pH}$ of $\leq 5.5$ will affect the biotic activity and growth of fungal cells and various other microflora in the rhizosphere [31]. Many species of fungi in the genus Trichoderma have the ability to establish special relationships with their hosts [32-33] as bio control agents. Fungi like this 
in their activity in the rhizosphere will produce specific molecules that encourage the emergence of plant responses in compounds that are important in defense mechanisms against pathogens such as $\mathrm{H}_{2} \mathrm{O}_{2}$, anthocyanins, camalexin, and various induced proteins [34-35]. In this case, soybean plants use more energy and metabolites to produce defense compounds for pathogens. Therefore, it appears that all plant growth parameters treated with the Tc-Jro-01 bio-fertilizer showed the lowest values. On acid growing medium soil ( $\mathrm{pH} 4.5$ ) (Table 2), the population of Tc-Jjr-01 isolate showed the lowest population of 0.96 $\mathrm{x} 10^{7} \mathrm{CFU} \cdot \mathrm{g}^{-1}$ compared to other isolates (Table 1,2). This is in line with the fact that the biomass of Trichoderma fungi in Czapeks-dox liquid medium decreased from an average of $1.35-1.40 \mathrm{~g}$ at $\mathrm{pH} 6.5$ to $1.20-1.36$ at $\mathrm{pH} 4.5$ [13]. The results of this experiment indicated that there was a difference in the sporulation response among the Trichoderma isolates tested (Table 2). Some Trichoderma isolates were reported to show no difference in sporulation levels at $\mathrm{pH} 4$ compared to $\mathrm{pH}$ 6, while several other Trichoderma isolates showed a higher total spore at $\mathrm{pH} 6$ than at $\mathrm{pH} 4$ [36].

\section{Conclusion}

Soybean varieties had a significant effect on plant height, wet weight, and dry weight of roots and stover at the age of 21 days after planting (DAP). The Burangrang variety showed better growth ability on acid soils than the Detam 3, Detam 4, Gema, and Dering 1 varieties. This variety showed an average plant height of $51.20 \pm 4.71 \mathrm{~cm}$, wet weight and dry weight of roots $1.45 \pm 0.15$ and $0.24 \pm 0.04 \mathrm{~g}$, wet weight and dry weight of stover $2.80 \pm 0.36$ and $1,45 \pm 0.14$ g per plant at $21 \mathrm{DAP}$. There was no interaction between soybean varieties and Trichoderma isolates formulated in biofertilizers. The isolate of Trichoderma Tc-Jjr-02 increased the wet weight and dry weight of roots and increased the wet weight and dry weight of the stover of soybean plants by 48.2 and $54.5 \%$ and 38.9 and $48.2 \%$, respectively, compared to without Trichoderma. Trichoderma biofertilizer application cannot reduce soil acidity.

Acknowledgements. The author would like to thank the Ministry of Education, Culture, Research, and Technology of the Republic of Indonesia for the 2021 Higher Education Excellence Basic Research Program Grant (PDUPT).

\section{References}

1. S.M. Hasan. Soybean - Bio-Active Compounds.doi:10.5772/54545 (2013)

2. C. Bustingorri and R.S. Lavado. Sci. Agric. (Piracicaba, Braz.), 68 (1): 102-108 (2011)

3. Badan Pusat Statistik (BPS). https://www.bps.go.id/ linkTableDinamis/view/id/870 retrieved May 1. 2017 (2016)

4. A. Wijanarko and A. Taufiq. Agrivita. 38(1):14-23 (2016)

5. S. Silva. Journal of Botany, 1-8. doi:10.1155/2012/219462 (2012)

6. H. Kuswantoro. International Journal of Plant Biology 5:5566. (2014)

7. D. Tamene, B. Anbessa, and T. Adisu. Adv Crop Sci Tech 5: 323 (2017)

8. M.I. Uguru, B.C. Oyiga, and E.A. Jandong. The African Journal o Plant Science and Botechnology. 6(1):26-37 (2012)

9. H. Kuswantoro. Int. J. Plant Breed. Genet., 9(3): 189-197 (2015) 
10. A. Singh, N. Shukla, B.C. Kabadwal, A.K. Tewari, and J. Kumar. Int.J.Curr.Microbiol.App.Sci 7(2): 2382-2397 (2018)

11. F. Vinale, K. Sivasithamparam, E.L. Ghisalberti, S.L. Woo, M. Nigro, R. Marra, N. Lombardi, A. Pascale, M. Ruocco, S. Lanzuise, G. Manganiello, and M. Lorito. Open Mycol. J. 8: 127-139 (2014)

12. M. Li, G. Ma, H. Lian, X. Su, Y. Tian, W. Huang, J. Mei, and X. Jiang. Journal of Integrative Agriculture, 18(3), 607-617 (2019)

13. S.C. Kolli, A. Nagamani, and R.Y. Rahel. International Journal of Environmental Biology 2(4): 180-182 (2012)

14. S.S. Moosavi, Y. Alaei, and A.M. Khanghah. International Journal of Agriculture and Forestry, 4(3A): 12-17 (2014)

15. Sutarman, A.E. Prihatiningrum, A. Sukarno, and A. Miftahurrohmat. IOP Publishing IOP Conf. Series: Materials Science and Engineering 420012064 (2018)

16. S. Teekachunhatean, N. Hanprasertpong, and T. Teekachunhatean. International Journal of Agronomy, 1-11 (2013)

17. Suryantini. Journal of Experimental Biology and Agricultural Sciences, 2(1):78-83 (2014)

18. E.F. Caires, G. Barth, F.J. Garbuio, and S. Churka. Sci. Agric. 65(5): 532-540 (2008)

19. V.B. Serafim, D.B. Oginga, and M.J. Njeri.. International Journal of Agricultural Science Research 2(9): 283-291(2013)

20. W. Bekere, T. Kebede, and J. Dawud. International Journal of SoilScience 8(1): 2531 (2013)

21. A.J. Mossi, G.F. Pauletti, L. Rota, S. Echeverrigaray, I.B.I. Barros, J.V. Oliveira, N. Paroul, and R.L. Cansian. Braz. J. Biol. 71(4): 1003-1009 (2011)

22. Balitkabi. Balitkabi. Malang (2016)

23. P. Chowdappa, S.P.M. Kumar, M.J. Lakshmi, and K.K. Upreti. Biol. Control, 65(1):109-117 (2013)

24. S. Lee, M. Yap, G. Behringer G, Hung, and J.W. Bennett. Fungal Biology and Biotechnology, 3(1).doi:10.1186/s40694-016-0025-7 (2016)

25. S.A. Youssef, K.A. Tartoura, and G.A. Abdelraouf . Biological Control 100, 79-86 (2016)

26. K. Saranavakumar and M.H. Wang. Physiol. and Molecular Plant Pathol. https://doi.org/10.1016/j.pmpp.2020.101458 (2020)

27. X. Hu, D.P. Roberts, L. Xie, J.E. Maul, C. Yu, Y. Li, Y. Zhang, L. Qin, and X. Liao. Phytopathology 105(10):1325-1333 (2015)

28. B.G. Anam, M.S. Reddy, and Y.H. Ahn. Sci. Total Environ. 662: 462-469 (2019)

29. M.Á. Agulló-Antón, E. Olmos, J.M. Pérez-Pérez, and M. Acosta. Plant Science, 201202, 1-11 (2013)

30. J. Mei, L. Wang, X. Jiang, B. Wu, and M. Li. BioMed Research International, 110. doi:10.1155/2018/8149682 (2018)

31. A. Kidanemariam, H. Gebrekidan, T. Mamo, and K. Kibret. Open Journal of Soil Science, 2: 223-233 (2012)

32. B. Baiyee, S. Ito, and A. Sunpapao. Physiol. Mol. Plant P. 106: 96-101 (2019)

33. K. Saravanakumar, C. Yu, K. Dou, M. Wang, Y. Li, and J. Chen. Biol. Control. 94: 37-46 (2016) 
34. M. Kottb, T. Gigolashvili, D.K. Großkinsky, and B. Piechulla. Front. Microbiol. 6:995 (2015)

35. F. Zhang, H. Ge, F. Zhang, N. Guo, Y. Wang, L. Chen, X. Ji, and C. Li. Plant Physiology and Biochemistry, 100, 64-74 (2016)

36. H.Z. Ali, H.M. Aboud, N.S. Dheyab, N.K. Musa, and F.H. Gasam. Int. J. Phytopathol. 4(1): 15-22 (2015). 